\title{
Processing of transparent glass-ceramics by nanocrystallisation of $\mathrm{LaF}_{3}$
}

\author{
N. Hémono, G. Pierre, F. Muñoz, A. de Pablos-Martín, M.J. Pascual *, A. Durán \\ Instituto de Cerámica y Vidrio (CSIC), C/Kelsen 5, Campus de Cantoblanco, 28049 Madrid, Spain
}

Received 18 February 2009; received in revised form 4 May 2009; accepted 7 May 2009

\begin{abstract}
Transparent glass-ceramics have been prepared by heat-treating oxyfluoride glasses in the $\mathrm{Na}_{2} \mathrm{O}-\mathrm{Al}_{2} \mathrm{O}_{3}-\mathrm{SiO}_{2}-\mathrm{LaF}_{3}$ system. The nanocrystallisation of $\mathrm{LaF}_{3}$ was achieved by controlling time and temperature parameters. Glasses and glass-ceramics were characterised by dilatometry, DTA, XRD and TEM. The mean crystal size $(<20 \mathrm{~nm})$ and the crystal fraction increase with the temperature of heat treatment, while they reach a maximum at about $20 \mathrm{~h}$ at a temperature close to $T_{\mathrm{g}}$. The crystallisation of phases containing glass modifier elements as well as $\mathrm{F}$ anions leads to the increase in the viscosity of the remaining glass matrix. Phase separation occurs in glass-ceramics depending on the glass composition which affects nanocrystallisation.
\end{abstract}

(C) 2009 Elsevier Ltd. All rights reserved.

Keywords: B. Grain size; D. Silicate; D. Halides; D. Glass-ceramics; Nanocrystals

\section{Introduction}

Fluoride crystals and glasses are characterised by low phonon energy, optical transparency and rare-earth ion solubility that make them suitable for optical amplifiers and up-conversion devices and lasers. ${ }^{1-4}$ However, fluoride crystals are costly to produce and fluoride glasses are characterised by poor chemical durability and mechanical stability. In transparent oxyfluoride glass-ceramics the optical active ion may be incorporated into a fluoride crystalline phase, thus offering a better alternative to both fluoride glasses and crystals. ${ }^{5}$

Wang and Ohwaki reported the first transparent $\mathrm{PbF}_{2}$ containing oxyfluoride glass-ceramic obtained by heat treatment. ${ }^{6}$ Dejneka reported $\mathrm{LaF}_{3}$-containing glass-ceramics as a more suitable host for rare-earth ions (RE) due to the better solubility of $\mathrm{LaF}_{3}$ for $\mathrm{RE}$ than $\mathrm{PbF}_{2} \cdot{ }^{7}$ A large concentration of nanocrystals with narrow size distribution is required in order to minimize the scattering losses in photonic applications, which can be done by controlling the nucleation and crystal growth within the glass matrix. The crystallisation studies are usually focused on isochemical systems, in which both crystals and glass matrix have the same composition that is not the case in $\mathrm{Na}_{2} \mathrm{O}-\mathrm{Al}_{2} \mathrm{O}_{3}-\mathrm{SiO}_{2}-\mathrm{LaF}_{3}$ system, where only

\footnotetext{
* Corresponding author.

E-mail address: mpascual@icv.csic.es (M.J. Pascual).
}

$\mathrm{LaF}_{3}$ will crystallise. Rüssel explained the nanocrystallisation of $\mathrm{CaF}_{2}$ in silicate glasses through the increase in the viscosity of the remaining glass matrix. ${ }^{8}$ The crystal-glass interface acts as a diffusional barrier and notably decelerates the crystal growth velocity that leads to the crystallisation of nanocrystals with size in the range from $10 \mathrm{~nm}$ to $50 \mathrm{~nm}$. The crystallisation behaviour, structure and the fluorescence properties of $\mathrm{Na}_{2} \mathrm{O}-\mathrm{Al}_{2} \mathrm{O}_{3}-\mathrm{SiO}_{2}-\mathrm{LaF}_{3}$ and $\mathrm{Er}^{3+}$ and $\mathrm{Yb}^{3+}$-doped glass-ceramics have already been investigated ${ }^{9-17}$ but the nucleation-crystal growth process and the variation on the size and number of crystals as a function of the thermal treatment as well as the interface characteristics need to be studied. The present work is based on this objective and constitutes a preliminary study on the processing and characterisation of transparent $\mathrm{LaF}_{3}$-containing glass-ceramics. Glasses and glassceramics have been characterised by dilatometry, differential thermal analysis, X-ray powder diffraction and transmission electron microscopy in order to determine the influence of the composition and the time-temperature conditions on the size and the quantity of nanocrystals.

\section{Experimental}

\subsection{Processing of glass-ceramics}

The oxyfluoride glasses were prepared by melting reagent grade $\mathrm{SiO}_{2}$ (Saint Gobain, 99.6\%), $\mathrm{Al}(\mathrm{OH})_{3}$ (Aldrich) or $\mathrm{Al}_{2} \mathrm{O}_{3}$ 
Table 1

Nominal and analysed compositions (in mol\%), glass transition temperatures $\left(T_{\mathrm{g}}\right)$ and the temperature of the maximum of the crystallisation peak $\left(T_{\mathrm{c}}\right)$ of the three transparent oxyfluoride glasses.

\begin{tabular}{|c|c|c|c|c|c|c|}
\hline & \multicolumn{2}{|c|}{$40 \mathrm{Si}-12 \mathrm{La}$} & \multicolumn{2}{|c|}{$40 \mathrm{Si}-10 \mathrm{La}$} & \multicolumn{2}{|c|}{$55 \mathrm{Si}-10 \mathrm{La}$} \\
\hline $\mathrm{SiO}_{2}$ & 40 & 45.5 & 40 & 39.3 & 55 & 56.4 \\
\hline $\mathrm{Na}_{2} \mathrm{O}$ & 18 & 16.5 & 20 & 18.2 & 15 & 13.6 \\
\hline $\mathrm{LaF}_{3}$ & 12 & 7.5 & 10 & 6.6 & 10 & 7.8 \\
\hline $\mathrm{La}_{2} \mathrm{O}_{3}$ & 0 & 4.8 & 0 & 2.9 & 0 & 2.4 \\
\hline$T_{\mathrm{c}}\left({ }^{\circ} \mathrm{C}\right) \pm 2{ }^{\circ} \mathrm{C}$ & 685 & 875 & 706 & & & \\
\hline
\end{tabular}

(Panreac), $\mathrm{Na}_{2} \mathrm{CO}_{3}$ (Panreac, 99.5\%) and $\mathrm{LaF}_{3}$ (Panreac, 99\%) in an electric furnace. The batches were first calcined in covered platinum crucibles up to $1300-1400^{\circ} \mathrm{C}$ and then melted $2 \mathrm{~h}$ within the temperature range of $1450-1600{ }^{\circ} \mathrm{C}$ depending on composition. The melts were quenched in air onto a brass mould and then annealed above the glass transition temperature. Glass-ceramics were obtained by controlled crystallisation of $\mathrm{LaF}_{3}$ by using cubic samples that were heat treated at temperatures between $T_{\mathrm{g}}$ and $T_{\mathrm{g}}+100^{\circ} \mathrm{C}$ in steps of 20 or $25^{\circ} \mathrm{C}$ during $20 \mathrm{~h}$. Kinetics studies were also performed in order to determine the influence of the treatment time at temperature close to $T_{\mathrm{g}}$ (from $10 \mathrm{~h}$ up to $72 \mathrm{~h}$ ).

\subsection{Characterisation of glasses}

The base glass compositions were chemically analysed by $\mathrm{X}$-ray fluorescence and flame photometry.

Glass transition temperature $\left(T_{\mathrm{g}}\right)$ was determined by dilatometry in a Netzsch Gerätebau dilatometer, model 402 EP, using a $2{ }^{\circ} \mathrm{C} \mathrm{min}^{-1}$ heating rate in air. The estimated error on $T_{\mathrm{g}}$ is $\pm 2{ }^{\circ} \mathrm{C}$. Differential thermal analysis (DTA) was performed on a Netzsch HSTA 409 with a heating rate of $10^{\circ} \mathrm{C} \mathrm{min}^{-1}$ in air and a particle size range of 500-800 $\mu \mathrm{m}$.

Oxyfluoride glasses and glass-ceramics were characterised by transmission electron microscopy (TEM) in a Hitachi H7100 employing the carbon replica method. The samples were chemically etched with a 5\% HF solution during $20 \mathrm{~s}$.

Powder XRD analyses were carried out with a D-5000 Siemens diffractometer using monochromatic $\mathrm{Cu} \mathrm{K} \alpha$ radiation $(1.5418 \AA)$. After checking the crystallisation of $\mathrm{LaF}_{3}$, the angular range $22-30^{\circ}(2 \theta)$ with a step length of $0.03^{\circ}(2 \theta)$ and a fixed counting time of $12 \mathrm{~s} /$ step was chosen to record the $\mathrm{LaF}_{3}$ (llll) peak in optimum conditions in order to minimize the errors in the mean crystal size calculation.

\section{Results}

Table 1 summarises the nominal and analysed compositions (in $\mathrm{mol} \%$ ), glass transition temperatures and the temperature of the maximum of the crystallisation peak of the three oxyfluoride glasses belonging to the system $\mathrm{Na}_{2} \mathrm{O}-\mathrm{Al}_{2} \mathrm{O}_{3}-\mathrm{SiO}_{2}-\mathrm{LaF}_{3}$ studied in the present work. Chemical analysis of glass $40 \mathrm{Si}-12 \mathrm{La}$ demonstrates that the maximum incorporation of fluorine into the glass matrix, as expected in silicate glasses, is less than $5 \mathrm{wt} \%$, which corresponds to $10 \mathrm{~mol} \%$ of $\mathrm{LaF}_{3}$ in the nominal composition. The $\mathrm{LaF}_{3}$ content has been fixed at $10 \mathrm{~mol} \%$ for the other two glasses in order to avoid a big excess of $\mathrm{La}_{2} \mathrm{O}_{3}$ in the glass matrix after fluorine volatilisation. The use of aluminium hydroxide for glass $40 \mathrm{Si}-12 \mathrm{La}$ leads to a large difference between nominal and analysed compositions, which may be due to the highly hydrated $\mathrm{Al}(\mathrm{OH})_{3}$. The other two glasses were obtained using $\mathrm{Al}_{2} \mathrm{O}_{3}$, calcined at $800{ }^{\circ} \mathrm{C}$ during $12 \mathrm{~h}$, in order to optimize the agreement of $\mathrm{Al}_{2} \mathrm{O}_{3}$ content between nominal and analysed compositions.

Thermal treatments up to $T_{\mathrm{g}}+100^{\circ} \mathrm{C}$ of oxyfluoride glasses 40Si-12La and $55 \mathrm{Si}-10 \mathrm{La}$ showed crystallisation of $\mathrm{LaF}_{3}$ only, while it was not possible for glass $40 \mathrm{Si}-10 \mathrm{La}$. Whereas the oxyfluoride glass-ceramics remain transparent in the case of glass $40 \mathrm{Si}-12 \mathrm{La}$, the samples become translucent for heat treatment from $640^{\circ} \mathrm{C}$ in the case of glass $55 \mathrm{Si}-10 \mathrm{La}$.

Fig. 1 depicts the XRD pattern of glasses $55 \mathrm{Si}-10 \mathrm{La}$ treated $20 \mathrm{~h}$ at $620^{\circ} \mathrm{C}, 40 \mathrm{Si}-12 \mathrm{La}$ treated $20 \mathrm{~h}$ at $645^{\circ} \mathrm{C}$ and $40 \mathrm{Si}-10 \mathrm{La}$ treated at $680{ }^{\circ} \mathrm{C}$ during $20 \mathrm{~h}$. The XRD patterns of the two first glass-ceramics match that of hexagonal $\mathrm{LaF}_{3}$ (PDF file No. 320483) whereas 40Si-10La glass-ceramic matches that of $\mathrm{LaF}_{3}$, cristobalite (PDF file No. 75-1544) and an unknown phase. High alumina content (33 mol\%) might inhibit the crystallisation of single $\mathrm{LaF}_{3}$ phase at temperatures below crystallisation of cristobalite.

Figs. 2 and 3 display the XRD patterns, scanned over the angular range of $22-30^{\circ}(2 \theta)$, of the glass-ceramics obtained

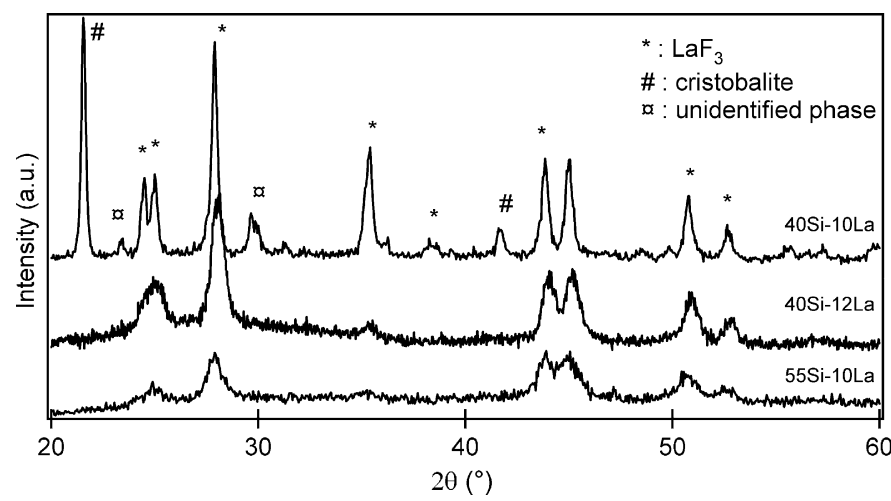

Fig. 1. XRD patterns of glasses $55 \mathrm{Si}-10 \mathrm{La}$ treated $20 \mathrm{~h}$ at $620^{\circ} \mathrm{C}, 40 \mathrm{Si}-12 \mathrm{La}$ treated $20 \mathrm{~h}$ at $645^{\circ} \mathrm{C}$ and $40 \mathrm{Si}-10 \mathrm{La}$ treated $20 \mathrm{~h}$ at $680^{\circ} \mathrm{C}$. 


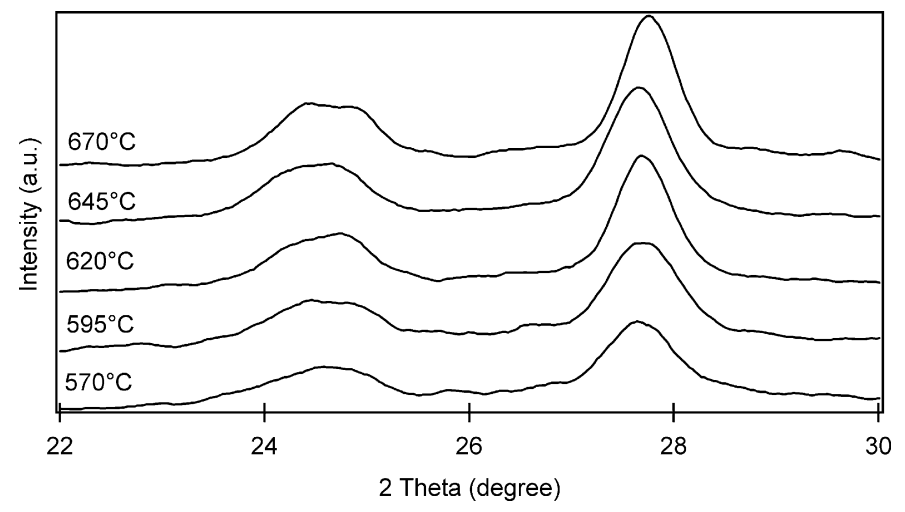

Fig. 2. XRD pattern of glass $40 \mathrm{Si}-12 \mathrm{La}$ treated $20 \mathrm{~h}$ from $570^{\circ} \mathrm{C}\left(T_{\mathrm{g}}\right)$ up to $670^{\circ} \mathrm{C}$.

by heat treatment at temperatures from $T_{\mathrm{g}}$ up to $T_{\mathrm{g}}+100^{\circ} \mathrm{C}$ during $20 \mathrm{~h}$. In both cases, the intensity of the diffraction peaks increases with the temperature of heat treatment, which is related to an increase in the crystal fraction. The XRD lines were fitted by curves of Gaussian shape. The size of the crystals has been calculated using the Scherrer equation on the $2 \theta \approx 27.5^{\circ}$ peak of $\mathrm{LaF}_{3}$ (1 111 ) from the patterns scanned over the angular range $22-30^{\circ}(2 \theta)$ with a step length of $0.03^{\circ}(2 \theta)$ and a fixed counting time of $12 \mathrm{~s} / \mathrm{step}$ following equation:

$D=\frac{G \lambda}{B \cos \theta}$

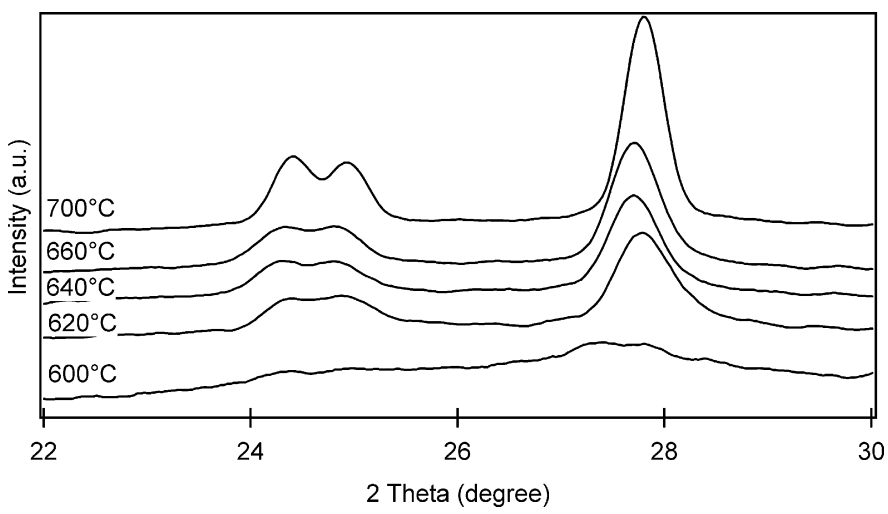

Fig. 3. XRD pattern of glass $55 \mathrm{Si}-10 \mathrm{La}$ treated $20 \mathrm{~h}$ from $600^{\circ} \mathrm{C}\left(T_{\mathrm{g}}\right)$ up to $700{ }^{\circ} \mathrm{C}$.

where $D$ is the mean crystal size, $G$ is a constant whose value is $0.9, \lambda$ the wavelength of $\mathrm{X}$-rays, $B$ the corrected full width at half maximum of the peak and $\theta$ the Bragg angle. The area under the $2 \theta \approx 27.5^{\circ}$ peak was also calculated to evaluate the trends in the crystal fraction which is proportional to the area under the peak. The errors for size and areas are given by the peak fit determination.

Fig. 4a depicts the variation of the mean crystal size as a function of time for glasses $40 \mathrm{Si}-12 \mathrm{La}$ and $55 \mathrm{Si}-10 \mathrm{La}$ treated at $570{ }^{\circ} \mathrm{C}\left(T_{\mathrm{g}}\right)$ and $620^{\circ} \mathrm{C}\left(T_{\mathrm{g}}+20^{\circ} \mathrm{C}\right)$, respectively. Both glassceramics show an increase in the mean crystal size up to $20 \mathrm{~h}$ treatment followed by an asymptotic limit. However, the size of
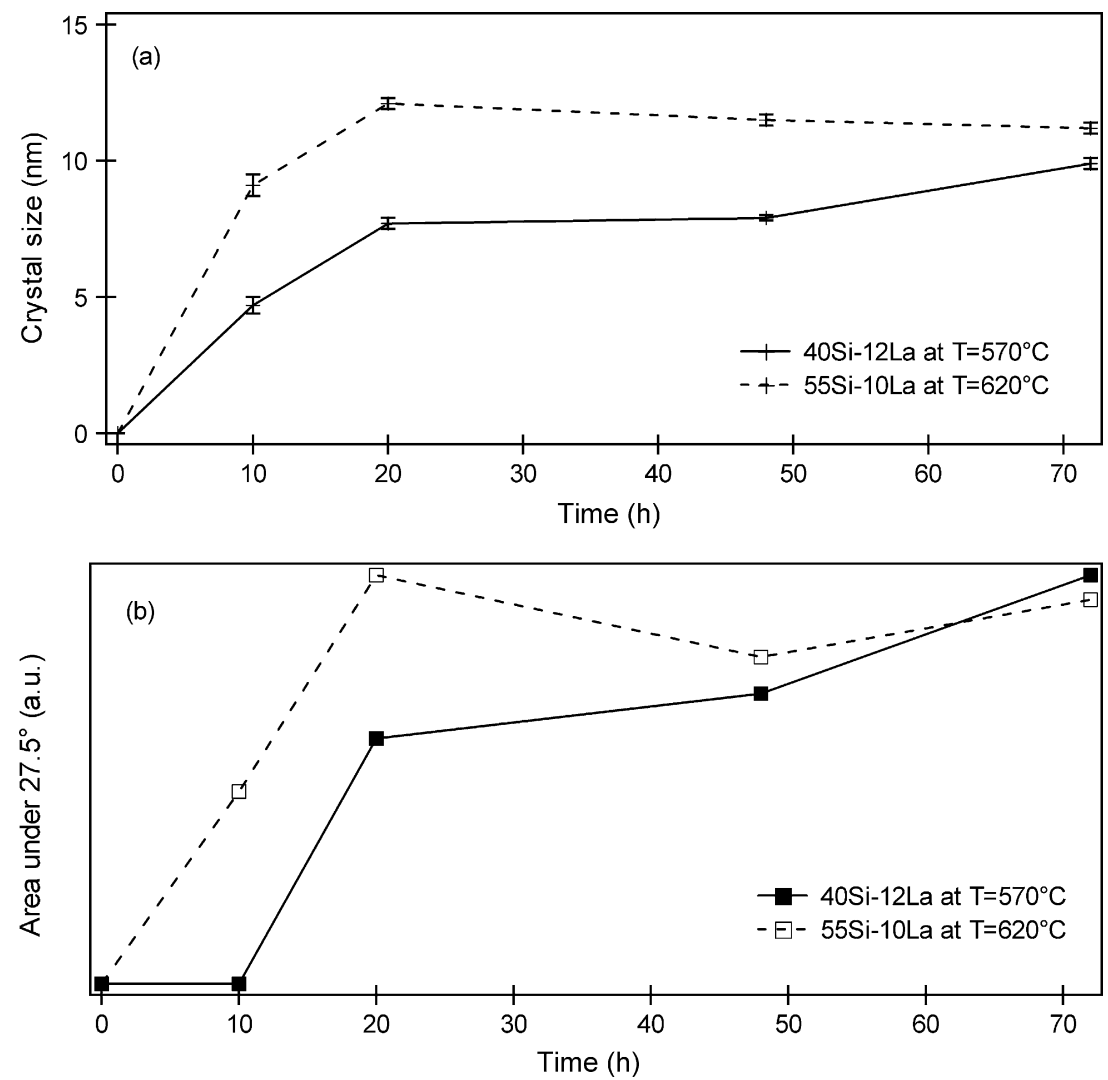

Fig. 4. Variation of the mean crystal size (a) and area under the $27.5^{\circ}$ diffraction peak (b) of glass $40 \mathrm{Si}-12 \mathrm{La}$ treated at $570{ }^{\circ} \mathrm{C}$ and glass $55 \mathrm{Si}-10 \mathrm{La}$ treated at $620^{\circ} \mathrm{C}$ as a function of time of heat treatment. The lines are drawn as a guide to the eyes. 

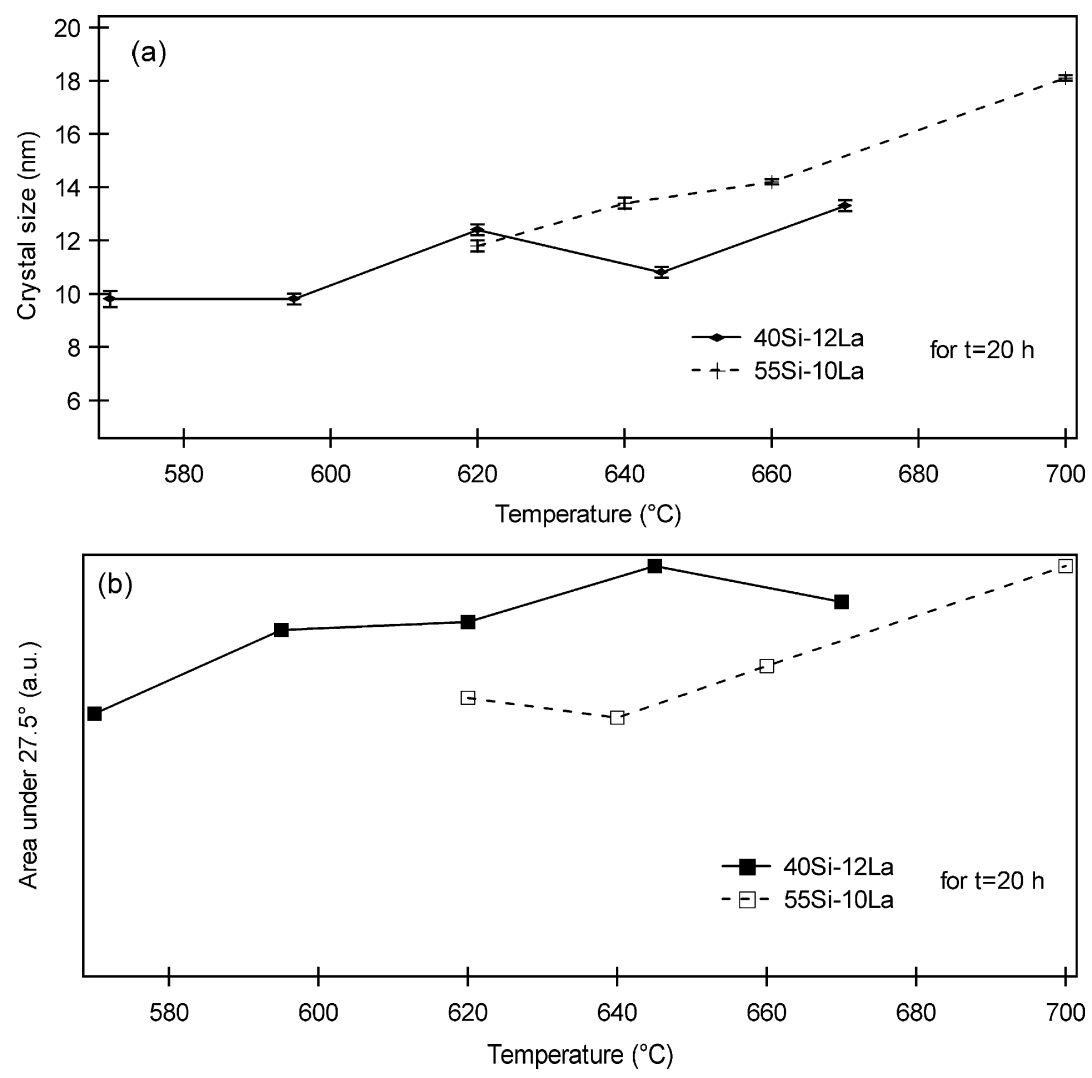

Fig. 5. Variation of the mean crystal size (a) and area under the $27.5^{\circ}$ diffraction peak (b) of glasses $40 \mathrm{Si}-12 \mathrm{La}$ and $55 \mathrm{Si}-10 \mathrm{La}$ treated during $20 \mathrm{~h}$ as a function of the temperature of heat treatment. The lines are drawn as a guide to the eyes.

the crystals reaches a bigger value for glass $55 \mathrm{Si}-10 \mathrm{La}$ within the whole time interval, being of $11 \mathrm{~nm}$ and $9 \mathrm{~nm}$ for glasses $55 \mathrm{Si}-10 \mathrm{La}$ and $40 \mathrm{Si}-12 \mathrm{La}$, respectively.

Fig. $4 \mathrm{~b}$ displays the variation of the area as a function of time of heat treatment for glass $40 \mathrm{Si}-12 \mathrm{La}$ treated at $570{ }^{\circ} \mathrm{C}$ and glass $55 \mathrm{Si}-10 \mathrm{La}$ treated at $620^{\circ} \mathrm{C}$. In both cases, the area increases up to $20 \mathrm{~h}$ of treatment while it remains approximately constant for longer treatment times.

Fig. 5a shows the variation of the mean crystal size as a function of temperature for glasses $40 \mathrm{Si}-12 \mathrm{La}$ and $55 \mathrm{Si}-10 \mathrm{La}$ treated during $20 \mathrm{~h}$. For both glasses, the mean crystal size slightly increases with temperature and the maximum size being smaller than $20 \mathrm{~nm}$. Fig. $5 \mathrm{~b}$ depicts the variation of the area as a function of temperature of heat treatment for glasses $40 \mathrm{Si}-12 \mathrm{La}$ and $55 \mathrm{Si}-10 \mathrm{La}$ treated during $20 \mathrm{~h}$, showing a slight increase within the temperature range studied.

Fig. 6 shows the variation of the glass transition temperature as a function of the treatment temperature of glasses $40 \mathrm{Si}-12 \mathrm{La}$ and $55 \mathrm{Si}-10 \mathrm{La}$ for a constant time of $20 \mathrm{~h}$. In both cases, $T_{\mathrm{g}}$ values are increasing linearly with the temperature of heat treatment while this variation is greater for glass $55 \mathrm{Si}-10 \mathrm{La}$.

Fig. 7 displays the TEM micrographs of the glass $40 \mathrm{Si}-12 \mathrm{La}$ (a) and its corresponding glass-ceramic obtained at $670{ }^{\circ} \mathrm{C}$ during $20 \mathrm{~h}$ (b). A droped-like phase separation can be observed in the base glass, which is enhanced after the thermal treatment as it can be seen in the micrograph of the glass-ceramic (Fig. 7b). This phase separation can be the responsible for the formation of agglomerates of around $100 \mathrm{~nm}$ of $\mathrm{LaF}_{3}$ crystals, at the same time that the nanocrystallisation takes place.

Fig. 8 displays the TEM micrographs of base glass $55 \mathrm{Si}-10 \mathrm{La}$ (a) and the glass-ceramic obtained at $700{ }^{\circ} \mathrm{C}$ during $20 \mathrm{~h}$ (b). In this case, a slight phase separation phenomenon is also observed but in a much less extent than in case of glass $40 \mathrm{Si}-12 \mathrm{La}$. Fig. $8 \mathrm{~b}$ shows a homogeneous distribution of crystals with an estimated size of $20-25 \mathrm{~nm}$, which is in good agreement with the calculation from the XRD pattern $(<20 \mathrm{~nm})$. Electron diffraction experiments confirmed the crystallisation of $\mathrm{LaF}_{3}$ in the two glass-ceramics.

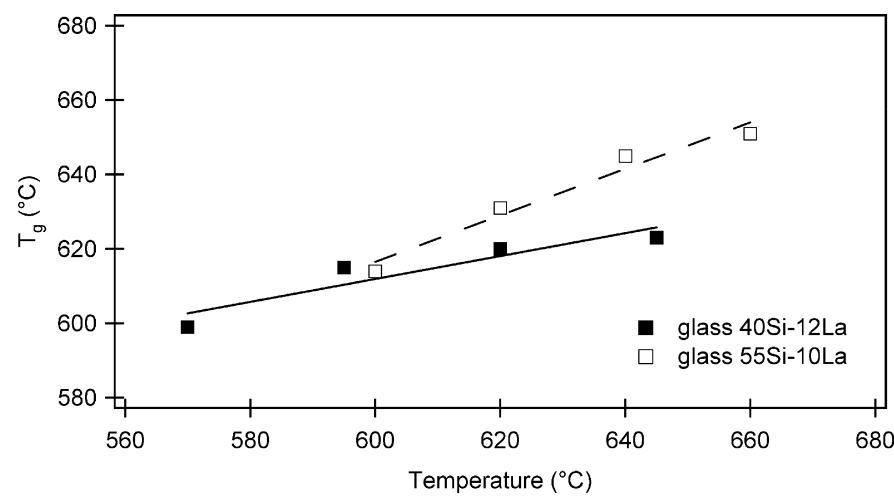

Fig. 6. Variation of the glass transition temperature of glasses 40Si-12La and $55 \mathrm{Si}-10 \mathrm{La}$ as a function of the treatment temperature for a constant time of $20 \mathrm{~h}$. 

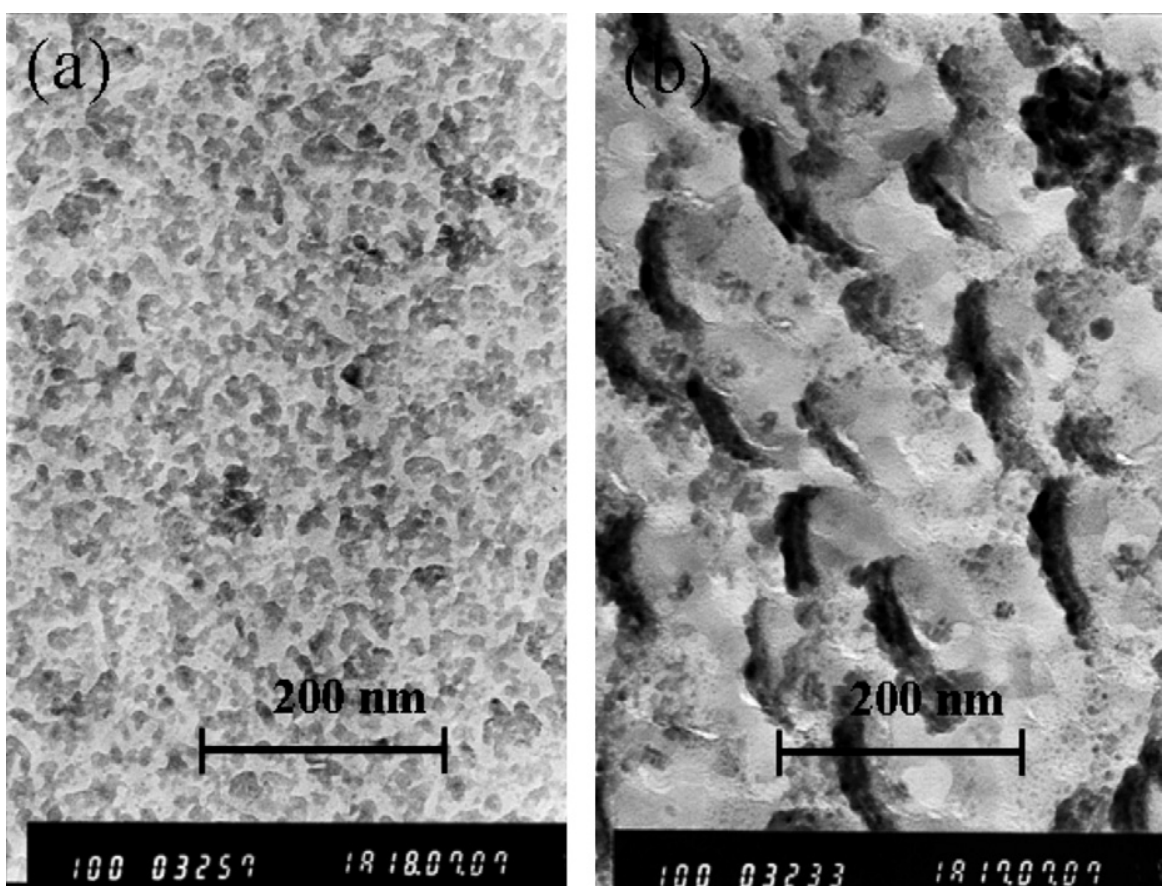

Fig. 7. TEM images of glass $40 \mathrm{Si}-12 \mathrm{La}$, (a) base glass and (b) glass-ceramic obtained after treatment at $670^{\circ} \mathrm{C}$ during $20 \mathrm{~h}$.
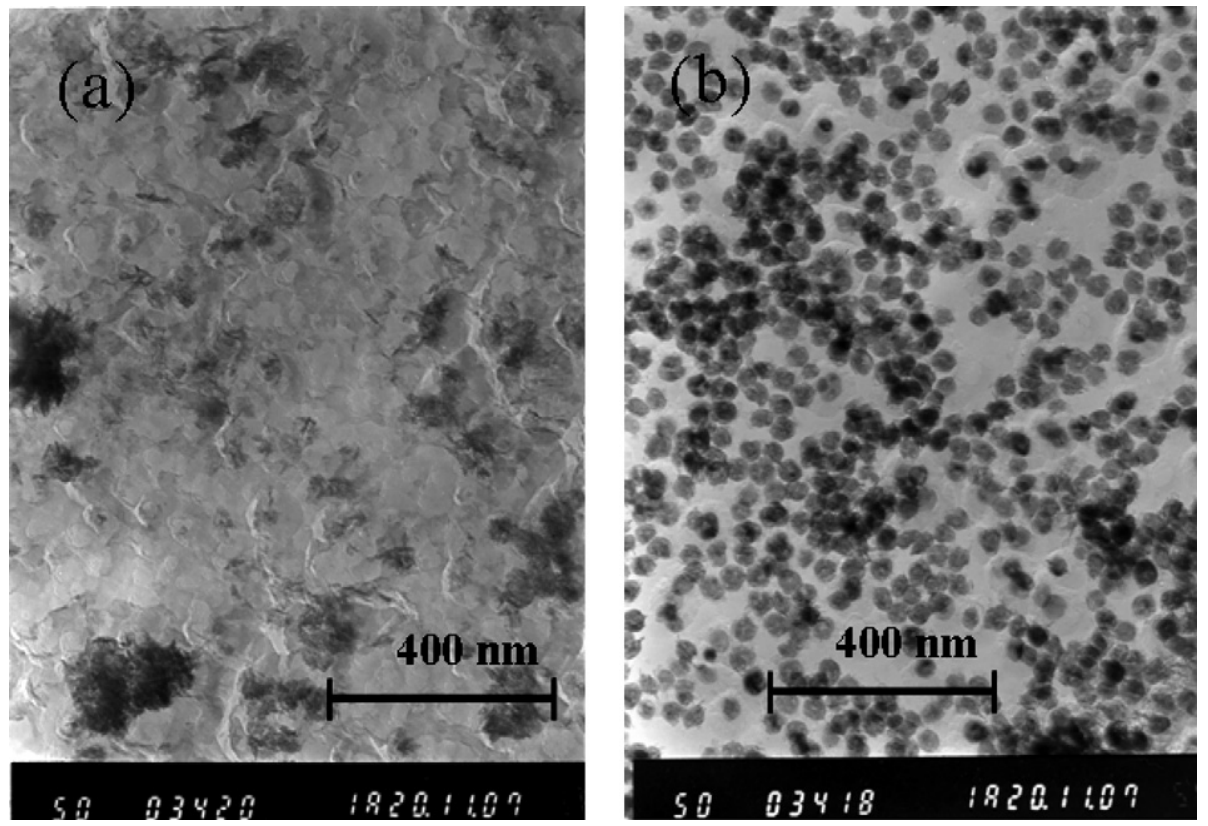

Fig. 8. TEM images of glass $55 \mathrm{Si}-10 \mathrm{La}$, (a) base glass and (b) glass-ceramic obtained after treatment at $700{ }^{\circ} \mathrm{C}$ during $20 \mathrm{~h}$.

\section{Discussion}

The $\mathrm{LaF}_{3}$ crystallisation behaviour has been shown to be similar for glasses $40 \mathrm{Si}-12 \mathrm{La}$ and $55 \mathrm{Si}-10 \mathrm{La}$ with regard of the mean crystal size and area. The size and crystalline fraction increase up to $20 \mathrm{~h}$ treatment at temperatures just above the glass transition temperature, while they remain approximately constant for longer treatment times. However, the growing in size and crystallisation of $\mathrm{LaF}_{3}$ is slightly bigger for the composition with higher $\mathrm{SiO}_{2}$ content (glass $55 \mathrm{Si}-10 \mathrm{La}$ ).
The nominal $\mathrm{SiO}_{2} / \mathrm{Al}_{2} \mathrm{O}_{3}$ ratios are $1.33,1.33$ and 2.75 for the studied glasses $40 \mathrm{Si}-12 \mathrm{La}, 40 \mathrm{Si}-10 \mathrm{La}$ and $55 \mathrm{Si}-10 \mathrm{La}$, respectively. However, chemical analyses show quite different values for glasses $40 \mathrm{Si}-12 \mathrm{La}$ and $40 \mathrm{Si}-10 \mathrm{La}$, i.e. 1.77 and 1.19 , respectively. Glass $40 \mathrm{Si}-10 \mathrm{La}$ showed the smallest tendency for crystallisation of single $\mathrm{LaF}_{3}$ phase at low temperatures. Thus, it can be assumed in this case, that the smaller the $\mathrm{SiO}_{2} / \mathrm{Al}_{2} \mathrm{O}_{3}$ ratio, the lower the crystallisation ability. Even though the treatment temperature of glass $55 \mathrm{Si}-10 \mathrm{La}$ was $T_{\mathrm{g}}+20^{\circ} \mathrm{C}$ in order to be able to calcu- 
late the mean crystal size, Fig. 4 shows a bigger size and amount of crystals as a function of time for glass $55 \mathrm{Si}-10 \mathrm{La}$ than for glass $40 \mathrm{Si}-12 \mathrm{La}$, which is in accordance with the biggest tendency for crystallisation as the $\mathrm{SiO}_{2} / \mathrm{Al}_{2} \mathrm{O}_{3}$ ratio increases.

On the other hand, crystal size and area slightly increase with treatment temperature for a constant time of $20 \mathrm{~h}$ for both glasses. In this case, there seems not to be a limit to the growing of crystals through the viscosity of the crystal-glass interface as in the case of $\mathrm{CaF}_{2}$-containing glass-ceramics studied by Rüssel. ${ }^{14}$ The crystalline fraction is assumed to increase within the temperature range studied at the same time that the mean crystal size increases from 10 to a maximum of $20 \mathrm{~nm}$.

Glass transition temperature increases with treatment temperature for both glasses $40 \mathrm{Si}-12 \mathrm{La}$ and $55 \mathrm{Si}-10 \mathrm{La}$, according to a decrease in the modifier content within the glass matrix composition after $\mathrm{LaF}_{3}$ crystallisation. Nevertheless, the slope of the increase is bigger for glass $55 \mathrm{Si}-10 \mathrm{La}$, which might be influenced at the same time by crystallisation as well as phase separation phenomena. If it only depended on the crystalline size and fraction, one may assume that a bigger crystallisation rate at a fixed temperature will lead to a bigger removal of glass modifiers from the glass matrix, thus giving rise to a more $\mathrm{SiO}_{2}$ and $\mathrm{Al}_{2} \mathrm{O}_{3}$ enriched glassy phase with a higher $T_{\mathrm{g}}$.

The nanocrystallisation behaviour in this system seems to be preceded by a phase separation process as shown in the TEM micrographs. A more completed study at the nanometer level using energy-filtered TEM imaging techniques (zero-loss filtering and elemental mapping) is to be published. ${ }^{18}$ In this work, it is revealed that La- and Si-enriched phase-separation droplets are precipitated already during the preparation of initial glass. Upon conversion of the glass in to a nano glass-ceramics by appropriate annealing, $\mathrm{LaF}_{3}$ nanocrystals are formed within these droplets. Excess silicon, also contained in the phase-separation droplets, is relocated towards the periphery of the droplets allowing only slight crystal growth.

\section{Conclusions}

Three oxyfluoride glass compositions in the system $\mathrm{Na}_{2} \mathrm{O}-\mathrm{Al}_{2} \mathrm{O}_{3}-\mathrm{SiO}_{2}-\mathrm{LaF}_{3}$ have been studied. Fluorine losses cannot be avoided and the maximum incorporation is less than $5 \mathrm{wt} \%$ (around $10 \mathrm{~mol} \%$ of $\mathrm{LaF}_{3}$ ). The formation of $\mathrm{LaF}_{3}$ single phase depends on the glass composition. Nanocrystals (size $<20 \mathrm{~nm}$ ) have been obtained; the mean crystal size and the crystal fraction increase with the temperature of heat treatment and reach a maximum at about $20 \mathrm{~h}$ of treatment at temperature near $T_{\mathrm{g}}$. Glass transition temperature increases with the temperature of treatment; the crystallisation of $\mathrm{LaF}_{3}$ leads to a decrease of network modifier in the residual glass matrix. A phase separation occurs in base glasses and glass-ceramics that might affect the nanocrystallisation process.

\section{Acknowledgement}

The authors acknowledge the financial support of Project INTERCONY, Contract No. NMP4-CT-2006-033200, from the Framework Programme 6 of the European Union.

\section{References}

1. Tran, D. C., Sigel Jr., G. H. and Bendow, B., Heavy metal fluoride glasses and fibers: A review. J. Lightwave Technol., 1984, LT-2(5), 566-586.

2. Ainslie, B. J., Davey, S. T., Szebesta, D., Williams, J. R., Moore, M. W., Whitley, T. and Wyatt, R., A review of fluoride fibres for optical amplification. J. Non-Cryst. Solids., 1995, 184, 225-228.

3. Yamada, M., Kanamori, T., Terunuma, Y., Oikawa, K., Shimizu, M., Sudo, S. and Sagawa, K., Fluoride-based erbium-doped fiber amplifier with inherently flat gain spectrum. IEEE Photon. Technol. Lett., 1996, 8(7), 882-884.

4. Downing, E., Hesselink, L., Ralston, J. and Macfarlane, R., A three-color solid-state, three-dimensional display. Science, 1996, 273, $1185-1189$.

5. Auzel, F., Pecile, D. and Morin, D., Rare earth doped vitroceramics: New, efficient, blue and green emitting materials for infrared up-conversion. $J$. Electrochem. Soc., 1975, 122, 101-107.

6. Wang, Y. and Ohwaki, J., New transparent vitroceramics codoped with $\mathrm{Er}^{3+}$ and $\mathrm{Yb}^{3+}$ for efficient frequency upconversion. Appl. Phys. Lett., 1993, 63(24), 3268-3270.

7. Dejneka, M. J., The luminescence and structure of novel transparent oxyfluoride glass-ceramics. J. Non-Cryst. Solids, 1998, 239, 149-155.

8. Rüssel, C., Nanocrystallization of $\mathrm{CaF}_{2}$ from $\mathrm{Na}_{2} \mathrm{O} / \mathrm{K}_{2} \mathrm{O} / \mathrm{CaO} / \mathrm{Al}_{2} \mathrm{O}_{3} / \mathrm{SiO}_{2}$ glasses. Chem. Mater, 2005, 17, 5843-5847.

9. Tanabe, S., Hayashi, H., Hanada, T. and Onodera, N., Fluorescence properties of $\mathrm{Er}^{3+}$ ions in glass ceramics containing $\mathrm{LaF}_{3}$ nanocrystals. Opt. Mater, 2002, 19, 343-349.

10. Goutaland, F., Jander, P., Brocklesby, W. S. and Dai, G., Crystallisation effects on rare earth dopants in oxyfluoride glass ceramics. Opt. Mater, 2003, 22, 383-390.

11. Środa, M., Waclawska, I., Stoch, L. and Reben, M., DTA/DSC study of nanocrystallisation in oxyfluoride glasses. J. Therm. Anal. Cal., 2004, 77, 193-200.

12. Hu, Z., Wang, Y., Bao, F. and Luo, W., Crystallization behavior and microstructure investigations on $\mathrm{LaF}_{3}$ containing oxyfluoride glass ceramics. J. Non-Cryst. Solids, 2005, 351, 722-728.

13. Ma, E., Hu, Z., Wang, Y. and Bao, F., Influence of structural evolution on fluorescence properties of transparent glass ceramics containing $\mathrm{LaF}_{3}$ nanocrystals. J. Lumin., 2006, 118, 131-138.

14. Reben, M., Waclawska, I., Paluszkiewicz, C. and Środa, M., Thermal and structural studies of nanocrystallisation of oxyfluoride glasses. J. Therm. Anal. Cal., 2007, 88, 285-289.

15. Reben, M., and Waclawska, I., Structure and nanocrystallization of $\mathrm{SiO}_{2}-\mathrm{Al}_{2} \mathrm{O}_{3}-\mathrm{Na}_{2} \mathrm{O}-\mathrm{LaF}_{3}$ glasses. Proceedings of the XXI International Congress on Glass. Strasbourg, France.

16. Chen, D., Wang, Y., Yu, Y. and Ma, E., Influence of $\mathrm{Yb}^{3+}$ content on microstructure and fluorescence of oxyfluoride glass ceramics containing $\mathrm{LaF}_{3}$ nano-crystals. Mater. Chem. Phys., 2007, 101, 464-469.

17. Jin, W., Xusheng, Q., Xianping, F. and Minquan, W., Preparation and luminescence of $\mathrm{Er}^{3+}$ doped oxyfluoride glass ceramics containing $\mathrm{LaF}_{3}$ nanocrystals. J. Rare Earths, 2006, 24, 67-71.

18. Bhattacharyya, S., Höche, Th., Hemono, N., Pascual, M. J., and van Aken, P. A., Study of nanocrystallization behavior in $\mathrm{LaF}_{3} / \mathrm{NaO} / \mathrm{Al}_{2} \mathrm{O}_{3} / \mathrm{SiO}_{2}$ glass using transmission electron microscopy. J. Cryst., submitted for publication. 